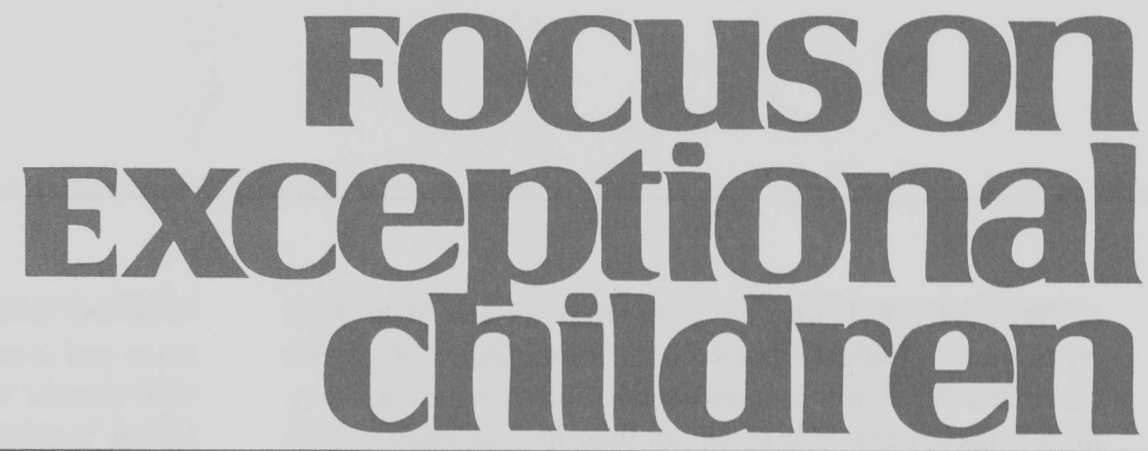

\title{
School Violence and Disruption: Rhetoric, Reality, and Reasonable Balance
}

\author{
Peter E. Leone, Matthew J. Mayer, Kimber Malmgren, and Sheri M. Meisel
}

During the past few years the specter of school violence has caused many parents, teachers, and administrators to rethink their basic assumptions about the safety of schools. Tragic and senseless shootings of students by students in public schools in the United States have left us stunned and distraught. Images of school shootings and the demand that schools become safe for all children have shaped responses by politicians, parents, and school administrators (Sheley, 2000).

Recent and widely publicized school shootings raise a number of questions: Are public schools less safe than they were 10 years ago? Twenty years ago? Can teachers teach and children learn in an atmosphere where concerns about safety interfere with instruction and management? In addition to these questions, parents and others want to know who has been involved in these school shootings and whether schools have taken steps to ensure that these incidents don't happen in their schools.

Most parents and members of communities believe that schools should be places where children develop intellectually and socially. The idea that school violence, in whatever form, interferes with the orderly operation and safety of schools is anathema to the public. Beyond concerns about physical injury to children, disruption of the school environment interferes with others' learning and can create a climate of fear in which children avoid school or engage in behaviors to protect themselves (Chandler et al., 1998). There is also the concern that minor problems, if ignored, will escalate into major events.

The most current data on school violence and youth victimization in the United States indicate that violence has been declining since 1993. Data reported by the Federal Bureau of Investigation as part of the Uniform Crime Reports (Rand, 1998), as well as students' self-report of victimization that are part of the National Crime Victimization Surveys (Brener et al., 1999), indicate that violence perpetrated by and against youth continues to fall. In spite of this, many segments of the public believe that school violence is increasing (Brooks, Schiraldi, \& Ziedenberg, 2000). Some of this misperception may be associated with the widely publicized school shootings at Columbine High School in Colorado and similar incidents in Kentucky, Oregon, and Michigan in the past few years.

Peter Leone, Ph.D., Professor at the University of Maryland, directs the National Center on Education, Disability, and Juvenile Justice, a project jointly funded by the Office of Special Education Programs of the U.S. Department of Education and the Office of Juvenile Justice and Delinquency Prevention of the U.S. Department of Justice. Matthew Mayer, a doctoral candidate in the Department of Special Education at the University of Maryland, specializes in school violence research. Kimber Malmgren, Ph. D., is an Assistant Professor in the Department of Special Education at the University of Maryland. Sheri Meisel, Ph. D., is Associate Director of the National Center on Education, Disability, and Juvenile Justice. 
Nevertheless, Uniform Crime Reports and data from other sources indicate that schools are the safest places for children to be. Fewer homicides and violent crimes are committed against children at school than in their homes or on the streets (Kaufman et al., 1998; Kaufman et al, 1999; Snyder \& Sickmund, 1999). Students" are greater than 100 times more likely to be the victim of a homicide away from school than at school (Kaufman et al., 1998).

Another issue that occasionally surfaces when the discussion turns to school violence is the role played by students with mental health problems or other disabling conditions. Some critics believe that special education rules and regulations have tied school principals' hands with regard to discipline and students with disabilities (Hymowitz, 2000). The most recent reauthorization of IDEA (Individuals with Disabilities Education Act) in 1997, however, gave schools a great deal of latitude in responding to disciplinary problems exhibited by students with disabilities. Principals can unilaterally remove special education students involved in weapons or drug offenses and those at risk of harming themselves or others and place them in interim alternative programs (Bear, 1999).

\section{Focuson
Exceptional
children}

ISSN 0015-511X FOCUS ON EXCEPTIONAL CHILDREN (USPS 203-360) is published monthly except June, July, and August as a service to teachers, special educators, curriculum specialists, administrators, and those concerned with the special education of exceptional children. This publication is annotated and indexed by the ERIC Clearinghouse on Handicapped and Gifted children for publication in the monthly Current Index to Journals in Education (CIJE) and the quarterly index, Exceptional Children Education Resources (ECER). The full text of Focus on Exceptional Children is also available in the electronic versions of the Education Index. It is also available in microfilm from Xerox University Microfilms, Ann Arbor, MI. Subscription rates: Individual, \$30 per year; institutions, $\$ 40$ per year. Copyright (C) 2000, Love Publishing Company. All rights reserved. Reproduction in whole or part without written permission is prohibited. Printed in the United States of America. Periodicals postage is paid at Denver, Colorado. POSTMASTER: Send address changes to:

\section{Love Publishing Company \\ Executive and Editorial Office P.O. Box 22353 \\ Denver, Colorado 80222 \\ Telephone (303) 221-7333}

$\begin{array}{cc}\begin{array}{c}\text { Karen Harris } \\ \text { University of Maryland }\end{array} & \begin{array}{c}\text { Thomas Skrtic } \\ \text { University of Kansas }\end{array} \\ \begin{array}{c}\text { James Shriner } \\ \text { University of Illinois }\end{array} & \begin{array}{c}\text { Stanley F. Love } \\ \text { Publisher }\end{array}\end{array}$

In this article we examine issues related to school violence and disruption. We begin by examining the sociocultural context within which school violence occurs, using a nested ecological schema. The first section presents a review of major changes in the status of children and their families, a discussion of availability and consequences of easy access to firearms, and the increase in prevalence of violence in popular media. We also examine media coverage of recent, widely publicized school shootings and the effect that media coverage has on parents' and students' perceptions of school safety. In the second section of the article, we examine prevalence and trends in school violence, with particular attention to the use of firearms on school property. This discussion explores some of the difficulty associated with defining and measuring school violence.

We then discuss the challenge of balancing the right to education with the importance of maintaining safe and orderly schools. In particular, we look at available data on the role of students with disabilities in school suspensions and discuss possible interpretations of these data. Finally, we examine how local schools and school districts have addressed violence and disruption in their buildings and communities. We describe violence-prevention initiatives and present guidelines for parents, teachers, and administrators to assist in ensuring that their schools are safe places that promote academic achievement and healthy behavior among all children and adolescents.

\section{THE CONTEXTS OF SCHOOL VIOLENCE}

School violence is a multifaceted phenomenon. Preventing school violence and responding to violent acts that occur within schools require an understanding of the larger community and society. Human behavior is shaped by socialecological contexts that include individuals with whom we interact daily as well as broad societal contexts that deliver messages about appropriate behavior and relationships among people (Bronfenbrenner, 1979). A widely accepted model (Tolan \& Guerra, 1994) of youth and family violence depicts a nested ecological system (see Figure 1) of individual factors, close interpersonal relations (e.g., peers and family), proximal social contexts (e.g., school and neighborhood), and societal macrosystems (e.g., media and laws governing gun use). Schools have created prevention activities and developed school-wide management plans that have reduced disciplinary referrals and suspensions, addressing risk factors and needs at multiple levels (TaylorGreen et al., 1997; Sugai, Sprague, Horner, \& Walker, 2000). These efforts and similar community-based initiatives have the potential to make schools more safe and orderly places for children. In this article, we will address aspects of the outer three levels of this nested system that 
surround the individual, looking at several school, family, and larger societal level factors.

The problem of school violence is linked to changes within our culture and society. Significant changes in family structure and changes in the status of children contribute to the problems that educators see in schools. Violence in the entertainment and news media has increased dramatically in recent years (Lichter, Lichter, \& Amundson, 1999) and contributes to a sense that youth are being negatively influenced

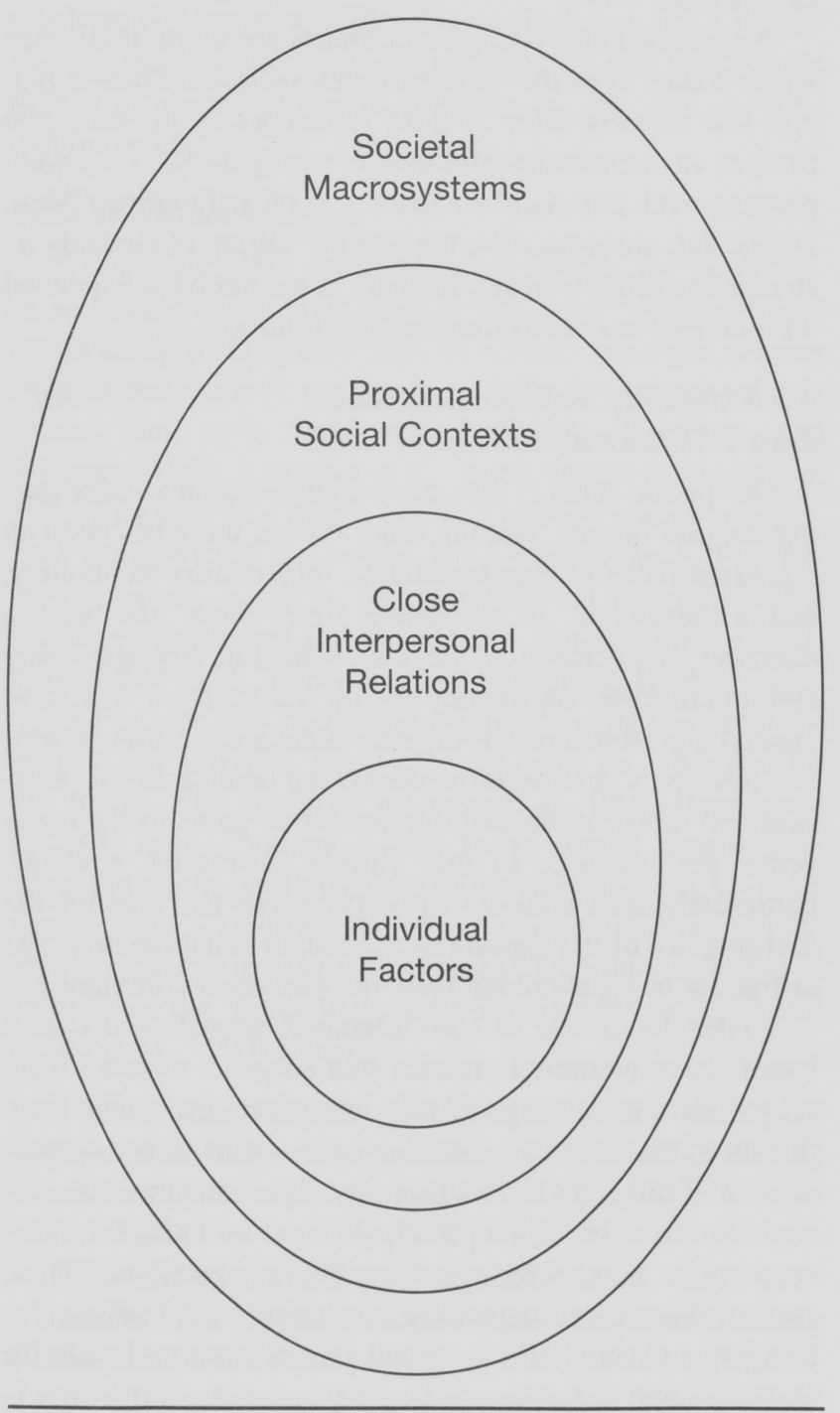

FIGURE 1

\section{A Nested Ecological System of Influences on Youth Behavior}

Source: Adapted from "Prevention of Delinquency: Current Status and Issues," (1994), by P. H. Tolan \& N. G. Guerra, Applied \& Preventive Psychology, 3, 254. by the movies they see, the television they watch, the popular music they hear, and the video games they play.

Many youths have easy access to guns (Ward, 1999). At the same time, print and broadcast news media regularly report on a wide range of violent crime committed not just in our own communities but in any hamlet served by an affiliate or a subsidiary of a large media conglomerate (Goldstein, 1994). It is difficult to establish causal relationships between school violence and changes in family structure, violent themes in popular entertainment, the availability of guns, and the reporting of violence by the news media. In each of these areas, however, there have been significant changes in recent years.

\section{Family Structure and Poverty}

Changes in family structure and changes in the relative distribution of income within society in recent decades have affected children. In 1950, fewer than $20 \%$ of all children in the United States lived in households that were dual-earner nonfarm families and one-parent families. At present, nearly two thirds of all children live in dual-earner nonfarm and one-parent families (Hernandez, 1995). The effect of this drastic change in living arrangements is that fewer adults are at home and available to support students during the nonschool hours. Although some of this change may have been offset by an increase in number of parents who work at home, evidence suggests that less time is available for parents to assist and monitor their children. Survey-based estimates suggest that from $4 \%$ to $23 \%$ of children regularly care for themselves, and several major surveys found that about $12 \%$ of children ages 5-12 were in self-care at least once a week (Kerrebrock \& Lewit, 1999; U.S. Department of Education, 1999b).

Another major change since 1980 that affects children has been a shift in the distribution of family income. While the mean income of families in the United States has risen, there has been an increasing gap between children in families living at the lowest income levels and those at the highest levels. From 1968 to 1994, income inequality in the United States increased 22.4\% (Weinberg, 1996). While the percentage of children living in luxury approaches $20 \%$, an even larger percentage of children live in relative poverty or near-poor frugality (Hernandez, 1995; U. S. Bureau of the Census, 1998; Weinberg, 1996).

More recent data from the U.S. Bureau of the Census, based on the Gini Index and quintile shares of aggregate household income (widely used measures of income inequality), show for the most part, from 1993 to 1998, no significant change in income distribution (A. Jones, personal communication, July 17, 2000). Poverty and the availability of parents to supervise their children do not directly create or cause school violence and or disruption. Nevertheless, 
poverty is one of a number of factors that place youth at risk for school failure, dropout, and delinquent behavior (Walker \& Sprague, 1999), and inadequate monitoring and supervision of children is associated with the development of antisocial behavior and delinquency (Patterson, 1982; Farrington, 1995; Hawkins et al, 2000).

\section{Violence in the entertainment industry}

A study by the Center for Media and Public Affairs documented the frequency with which violent images are featured in popular entertainment (Lichter et al., 1999). They examined made-for-television movies, television series, music videos, and movies, to determine the prevalence with which violent content was featured. They found that across all forms of entertainment, serious violent images or scenes were featured on the average of 14 times per hour of viewing. When just high violence shows were examined, they found an average of 54 violent acts per hour. Although causal effects between viewing violent images and engaging in violent or disruptive behavior in school are difficult to establish, evidence suggests that exposure to television violence does have an effect on violent behavior (American Psychological Association, 1993; Felson, 1996; Reiss \& Roth, 1993).

\section{Media Coverage of School Violence}

During the past few years, news media have ratcheted up their coverage of violence in communities and across the country. The evening news and the daily paper chronicle violent acts, both local and across the country, involving juveniles and adults. In the wake of the tragic events and the massive media blitz at Columbine High School in April, 1999, a USA Today poll found that $68 \%$ of Americans surveyed thought that it was likely or very likely that a school shooting could occur in their town. Other polls of parents' perceptions of school safety taken in the past year revealed similar results (Brooks, Schiraldi, \& Ziedenberg, 2000).

Consolidation within the media industry has placed control of radio, television, and newspapers in the hands of fewer and fewer companies (Howard, 1995). As corporate giants compete for audience share or circulation, reporting of violence has become a marketing tool to increase market share (Felson, 1996). Local events in one part of the country become national events as affiliate television and radio stations and newspapers carry reports throughout the country. Although juvenile crime rates fell in the 1990s, the public, informed by media coverage of violence, largely believed that juvenile crime was up and that schools were unsafe (Brooks et al., 2000).

\section{Access to Guns}

Handguns and other firearms are more widely available in the United States than in any other industrialized nation in the world, reflecting a permissive policy approach. A 1997 National Institute of Justice report estimated that approximately one third of all households in the United States have guns, with two thirds of gun owners possessing more than one gun (Cook \& Ludwig, 1997). At the time of a recent survey $20 \%$ of gun owners reported having unlocked, loaded guns in their houses (Cook \& Ludwig, 1997). In 1997, more than 4,200 children ages 0-19 were killed by firearms in the United States. More than 2,500 of these killings were homicides and another 1,200 were suicides (Ward, 1999).

Proportionately, young black males are more likely than white youths to be the victims of gun violence. Though federal law restricts sales of guns to minors by licensed gun dealers, in some states children as young as 12 can legally possess semi-automatic weapons and other firearms (Ward, 1999). Yet, unmistakably, the horrific killing of students by students in schools in recent years could not have happened without easy access to firearms by children.

\section{Accountability, Achievement, and \\ Zero Tolerance at the School Level}

Our public schools also have changed dramatically during the past decade. Among other things, there has been an increased focus on accountability, information technology, and achievement. At the same time, there has been a decrease in tolerance of deviant behavior. Accountability and an emphasis on literacy for the Information Age have created a greater sense of urgency among educators. Teachers, principals, and superintendents are being asked to measure and demonstrate tangible academic gains in their students' performance. In this climate, disruptive students, particularly those who score poorly on tests that measure the performance of the classroom, school, or school district, are at-risk for being excluded from the education community.

Under the mantle of zero tolerance, schools and school boards have instituted policies that suspend students from school for a wide range of rule infractions that range from threats of violence to possession of weapons to use or possession of drugs on school property. Zero tolerance has created situations in which principals have no latitude or discretion in administering disciplinary sanctions. Thus, students have been suspended for sharing Midol tablets, for bringing a plastic knife to spread peanut butter at lunch, for sharing cough drops, for displaying a manicure kit with a 1inch knife, and for sharing a prescription inhaler with a student experiencing anaphylactic shock (Tebo, 2000; Skiba \& Peterson, 1999).

In sum, changes in the family and the status of children, increases in violent images in popular entertainment, changes in media coverage of violent events, increased availability of guns, and increased accountability at school all set the 
stage for understanding the current state of school violence and disruption. In the next section, we examine authoritative reports concerning school violence and discuss the difficulty of measuring school violence.

\section{UNDERSTANDING SCHOOL VIOLENCE}

Interest in school violence is a relatively recent phenomenon. How we conceptualize and define school violence shapes how schools think about and respond to the problem (Furlong \& Morrison, 2000). Depending upon one's definition of the term, acts of school violence can range from threats of physical violence, to bullying, physical assaults, and homicide.

\section{Data on School Violence}

Schools are safer than individual homes and neighborhoods. Children are more likely to encounter serious violent crime away from school than at school. Multiple sources suggest that students are approximately three times safer in school than away from school (Elliott, Hamburg, and Williams, 1998; Kaufman et al., 1999; Snyder \& Sickmund, 1999). There is less than a one in a million chance of a student experiencing a school-related violent death. Furthermore, the vast majority of school-related injuries are not violence-related and the majority of school crime is nonviolent theft (U.S. Department of Education, 1999a).

The picture of school violence that has emerged over the past decade provides reason for concern, yet optimism for the future. The findings are mixed. In 1997, there were 202,000 serious violent crimes (rape, sexual assault, robbery, and aggravated assault) against students ages 12-18 in school and 2.7 million total school crimes (Kaufman et al., 1999). Centers for Disease Control (CDC) data collected in 1999 from the Youth Risk Behavior Surveillance (YRBS) (Kann et al., 2000) found:

$-6.9 \%$ carried weapons at school nationally during 30 days prior to the survey, with males $(11.0 \%)$ reporting much higher rates of weapon-carrying than females $(2.8 \%)$

$-7.7 \%$ of students nationally reported having been threatened or injured with a weapon on school property during the past 12 months

$-14.2 \%$ of students had been in a physical fight at school during the prior 12 months.

Some longer-term data show that certain measures of violence in schools have remained fairly constant over the past 20 years while other measures of violence have shown a clear pattern of decrease during the 1990s. For example, YRBS data (Centers for Disease Control and Prevention,
2000) show a steady, dramatic decline in students reporting having carried a weapon on school property during the 30 days prior to the survey, from $11.8 \%$ in 1993 to $6.9 \%$ in 1999 (see Figure 2).

The same YRBS data show a similarly impressive decline in students reporting having carried a gun during the 30 days prior to the survey, from $7.9 \%$ in 1993 to $4.9 \%$ in 1999. Also, from 1993 to 1999 , the percentage of students who reported having been in a physical fight at school during the 30 days prior to the survey dropped from $16.2 \%$ to 14.2\%. The Annual Report on School Safety (U.S. Department of Education, 1999a) also reports a decline in several measures of school violence during the 1990s.

Several indicators of school violence have remained fairly constant over the past 20 years. For example, from 1976 to 1997 , approximately $5 \%$ of high school seniors report having been injured with a weapon at school during the previous 12 months, according to data from the ongoing Monitoring the Future study (University of Michigan). During the same period, approximately $12 \%$ of seniors report having been injured without a weapon and about $12 \%$ report having been threatened with a weapon at school during the previous 12 months (U.S. Department of Education, 1999b; Institute for Social Research, 1997). Other data sources, such as the so-called Principals' and Disciplinarians' Report (U.S. Department of Education, 1998a), show relatively less crime in the schools. That report was based on incidents in which the school called the police. Understandably, administrators may be reluctant to call police or to submit reports suggesting that their school environment is out of control.

This discussion demonstrates that reported measures of school violence differ somewhat depending on the source. A reasonable question to ask is: Why do we see clear signs of decline in some measures, yet relative stability in other measures? Also, how do we decide whether, and to what extent, school violence and disruption is a serious problem? To begin to answer these questions, we need to consider a number of issues surrounding school violence, as well as community-based violence data collection and reporting.

\section{Making Sense of the Numbers}

National data on school violence come from several sources. Some sources focus on criminal acts per se, others focus on injury from a health agency perspective, and some privately commissioned surveys (e.g., Metropolitan Life Survey of the American Teacher) focus on various aspects of school violence. The FBI Uniform Crime Reporting (UCR) Program gathers reports from local law enforcement agencies directly or through respective state agencies (Cook \& Laub, 1998). As illustrated by Cook and Laub, the UCR data can seriously underestimate true levels of violent crime and provide no information on age of victim or assailant. 


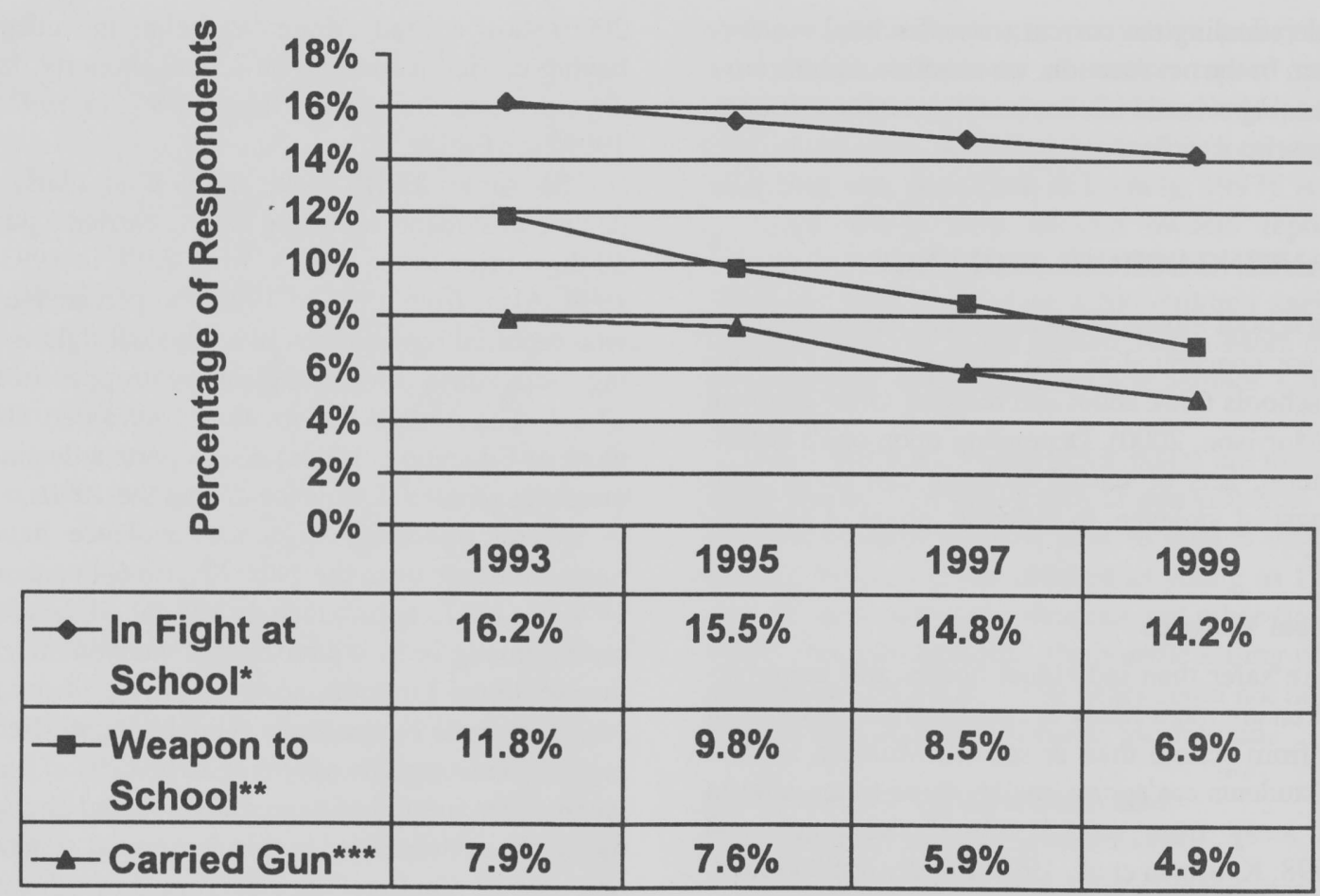

FIGURE 2

\section{Self-Report of Risk Related Behaviors: 1993-1999 Trends}

\footnotetext{
Source: Centers for Disease Control and Prevention. (2000). Fact Sheet: Youth Risk Behavior Trends

* Involved in a fight on school property at least one time during the 12 months preceding the survey

** Carried a weapon on school property at least one time during the 30 days preceding the survey

*** Carried a gun at least one time during the 30 days preceding the survey
}

Furthermore, some data on juvenile crime are presented in terms of arrests, whereas other data represent convictions. These two categories are quite different, as arrest figures can include innocent individuals (Loeber, Farrington, \& Waschbusch, 1998, p. 21). Arrests records do not offer a viable sample of actual crime perpetrators (Cook \& Laub, 1998). In addition, law enforcement agencies vary considerably in their reporting of data to the UCR system, thus making year-to-year and other comparisons risky.

A separate source of national level data on violence comes from the National Crime Victimization Survey (NCVS), using household interviews conducted every 6 months (since 1973), and from the School Crime Supplement (SCS) to the NCVS, which is conducted every 4 or 5 years. The NCVS provides information on victimization of youths age 12 and older. Like other forms of self-report, however, this one is subject to errors from a variety of sources, including sampling frame problems, instrument problems, and respondent errors such as inaccurate recall, comprehension problems, omissions, and telescoping effects (Biemer et al., 1991).

Data gathering methods to assess school violence vary considerably, and perceived violence is consistently reported at higher levels than self-reports of violent incidents (Furlong and Morrison, 1994). Methodologically, studies on school violence usually take a [confirmatory] hypothesis verification approach. That is, school violence is assumed to exist and survey questions elicit responses that confirm its existence. A Congressional Research Service report (U.S. Library of Congress, 1994) found problems in data collection efforts regarding school violence in terms of inconsistent definitions and wording of indicators, varying time frames among studies, and underreporting of criminal acts.

Reiss and Roth (1993) offer a detailed analysis of data collection issues pertaining to violence. They cite differences between UCR, NCVS, and National Center for Health Statistics (NCHS) data in terms of: "(a) domain of events, 
(b) unit of count, (c) timing of counting, and (d) sources of discretion and error in recording and counting events."

Furthermore, events that are measured are social constructs that depend on society's view of crime-something that changes over time. Reiss and Roth also note that crime incidents can be described differently as a function of the location and circumstance, whether they are defined in terms of the perpetrator (arrest) or victim (injury), and whether multiple offenders or offenses are involved. All of these issues can contribute to varying depictions of violent activity in the community as well as in schools.

Agencies responsible for data collection, analysis, and reporting have attempted to ameliorate the situation throughout the 1980s and 1990s. The CDC has supported many efforts to standardize definitions and reporting of injury-related data (CDC, 1997; Mercy, Ikeda, \& Powell, 1998). The National Education Statistics Agenda Committee (U.S. Department of Education, 1996) assessed the current status of data collection and reporting among the states regarding criminal and violent behaviors in schools. The committee issued a report describing the existing state of affairs, providing model definitions for data collection and a description of a model data system that states could choose to implement.

Reconciling the differences between CDC data showing a clear decline in school violence and Monitoring the Future data that shows stability over two decades is a challenge. The participants, time frames, and wording of questions differ between these surveys. For example, several of the CDC-YRBS survey questions pertain to frequency of weapon-carrying and involvement in a fight. Several of the questions from the Monitoring the Future survey pertain to being threatened or injured with a weapon, and having property damaged or stolen.

Although we may choose to think of these questions as proxy variables for school violence and disruption, just because they fall under a common umbrella concept does not necessarily mean that they measure the same behaviors. They each need to be evaluated within the context of the specific survey effort. Unfortunately, no existing procedure allows clear reconciliation of these data differences. The best one can do is to conclude that some serious problems remain with school violence, but that there are several clear signals of an improving situation and that, generally speaking, schools are safe.

\section{BALANCING EDUCATIONAL RIGHTS WITH AN ORDERLY SCHOOL ENVIRONMENT}

Public schools are charged with providing all children with educational opportunities. School administrators and teachers have a vested interest in creating environments in which their students can best learn. Given the diversity and the numbers of children who walk through the public school doors, this is no small feat. School systems and personnel must constantly balance the need for orderliness and efficiency in schools with the rights and entitlements of individual students. Although the needs and desires of school systems often are aligned with the needs and desires of the students they serve, at times the two are at odds.

In the following sections we will discuss some of the entitlements due students in general, and how these entitlements have affected schools' abilities to provide appropriate educational environments. We also will discuss the impact of those additional entitlements afforded students with disabilities, including some of the pitfalls and misperceptions associated with these entitlements.

\section{Educational Entitlements}

Compulsory school-attendance laws give children the right, as well as the responsibility, to attend school. Schools must serve all the children in their communities - even children who prefer not to attend. The public schools cannot pick and choose whom they serve, even if picking and choosing would result in more efficiency, higher achievement scores for the school as a whole, or less disruption.

Over time, compulsory school-attendance laws have created problems for schools in jurisdictions where schools and school districts have not adapted to their changing school clientele. Problems have included truancy, disruptive or disrespectful behavior, drug use, threats of violence, and acts of violence. As problems have cropped up, individual schools, school districts, and governmental agencies have crafted ways for schools to deal with those problems. Responses have included (and continue to include) the use of behavioral modification strategies, timeouts, and corporal punishment. For serious violations of the school code, schools have expelled students and placed them into alternative education settings (Yell, 1990; Yell, Cline, and Bradley, 1995; Yell, 1998, ch. 15). Sometimes these responses have been effective in restoring order to the school environment. Other times these responses have gone too far and threatened the rights of the students to whom they are applied.

The U.S. Supreme Court has examined the issue of school discipline on several occasions. In 1977, the Court examined the constitutionality of corporal punishment (Ingraham v. Wright, 1977). Although the Court eventually decided that corporal punishment did not constitute "cruel and unusual punishment" and that students were not entitled to a hearing prior to the administration of corporal punishment (under the due process clause of the 14th Amendment), the justices did reiterate that individual teachers or administrators could be held liable or subject to criminal penalties if the corporal punishment administered was later found to be 
excessive. Even though the Ingraham v. Wright decision did not change the legal status of corporal punishment, the very fact that the Supreme Court heard this case influenced state legislatures to pass additional laws governing the use of corporal punishment (Yell, 1990; Yell, 1998, ch. 15). Corporal punishment remains an option for schools in some states, but its use is limited by requirements such as approval by the principal, presence of an adult witness, and prior parental approval. These limitations protect individual students from capricious and overzealous use of corporal punishment by frustrated school personnel.

Another disciplinary action that has been called into question is suspension from school. In 1975, the U.S. Supreme Court heard Goss v. Lopez, in which nine high school students alleged that their constitutional right to due process (under the 14th Amendment) had been violated when they were each suspended for up to 10 days without a formal hearing. In this case, the Court sided with the students, declaring that schools must provide evidence of a student's misconduct at a hearing prior to (or immediately following) the suspension. The Court ruled that students' rights to attend school supersede schools' rights to unilaterally exclude students for misconduct. Although school suspensions for disciplinary purposes are allowable, the process must include oral or written notice of the offense and the right to be heard (Yell, 1998, ch. 15).

In Honig v. Doe (1988), the Supreme Court set the stage for revised procedures in dealing with aggressive and violent students. This contributed to a change in attitudes among educators, politicians, and the public with regard to the behavior of students with disabilities. Bill Honig, Superintendent of Instruction for California schools, argued that a dangerousness exclusion to the "stay-put provision" of disability law existed, whereby schools could exclude students who threatened the safety of others. The Court denied his argument and made it clear that the stay-put provision held, and that schools could not unilaterally remove students considered dangerous while their change of placement was being appealed.

The Court's ruling also supported the position that a suspension of more than 10 days is a change of placement. The court affirmed that normal procedures, including temporary suspensions of up to 10 days, timeout, study carrels, and detention could be used with dangerous students (Sorenson, 1993; Tucker, Goldstein, and Sorenson, 1993; Yell, 1998).

In the last 5 to 10 years, particularly in the aftermath of the Honig decision, a number of state and local education agencies have revised school disciplinary codes to reflect the tenor of recent Safe and Drug-Free Schools legislation (Skiba \& Peterson, 1999, 2000). This legislation was aimed at eliminating weapons and controlled substances on school grounds. This type of disciplinary approach-popularly referred to as zero tolerance-has serious flaws in its implementation. Some administrators have overlooked small infractions by otherwise well-behaved students (e.g., an honor student who forgets to remove a miniature Swiss army knife from his keychain), and others have enforced the letter of the law to such an unyielding extent that they attract national media attention (e.g., the second-grader who brought his grandfather's watch to show and tell; a 1-inch mini-pocketknife was attached; the student was suspended and sent to an alternative school for 1 month).

The real problem with a zero-tolerance posture is that serious punishments, such as suspensions from school, have been handed out in an arbitrary and inconsistent manner (Harvard University Civil Rights Project, 2000; Skiba \& Peterson, 1999; Tebo, 2000). Students with disabilities who have behavioral problems and who typically have few advocates in the schools, as well as African-American students, are particularly vulnerable to harsh disciplinary tactics (Harvard University Civil Rights Project, 2000; Townsend, 2000).

\section{Entitlements of Students with Disabilities}

Although basic educational entitlements apply to all students, those with disabilities are afforded separate, additional protections under the IDEA, most recently amended and reauthorized in 1997. Provisions of IDEA pertaining to discipline are frequently a source of contention. For example, if a student engages in aggressive or disruptive behavior as a consequence of his or her disability, a school is not at liberty to unilaterally suspend that child from school for that very behavior. This is not to say, however, that schools have no recourse whatsoever when a student with a disability misbehaves.

A wide-range of commonly used discipline tactics are still available to use with students with disabilities. These include behavior management strategies, restrictions on privileges, and in-school suspension. Even suspension from school is still an option as long as that suspension does not last 10 days or become part of a pattern of suspensions that accumulate up to 10 days in length.

The stay-put provision of IDEA (IDEA Regulations, 34 C.F.R. $\S 300.514$ ) is a common concern for teachers and administrators. When a student with a disability engages in serious acts of misconduct that could result in that student's removal from his or her current placement, school administrators and the student's parents often concur on a plan of action. When parents and school administrators disagree and parents request a due-process hearing, the stay-put provision comes into play. Under the stay-put clause, schools are not allowed to remove a student from his or her current placement while the disciplinary action is under review.

The stay-put provision often is misinterpreted to mean that children with disabilities can engage in dangerous conduct 
without fear of ever being removed to a more restrictive setting. To the contrary, if a student with a disability brings a weapon or controlled substance to school, that student is subject to the same disciplinary actions that apply to a student without a disability. The student then can be referred to an Interim Alternative Education Placement (IAEP).

Regardless of the disciplinary outcome, the school system must provide special education services to any student with a disability who ends up being suspended from school for more than 10 cumulative days in a school year. In addition, if a child with a disability engages in behavior that school administrators believe is likely to result in injury to self or others in the school community, the child with a disability can be removed to an IAEP for up to 45 days (Bear, 1999). The critical element is that the child with a disability not lose access to his or her educational services. The educational services provided to children with disabilitiesincluding services designed to address their behavioral and social-skill deficits-are critical to their eventual success.

Occasionally schools use homebound instruction as an IAEP. These cases seem to violate both the spirit and intent of IDEA discipline provisions. Homebound instruction typically is limited to about 6 hours per week. In such circumstances, it is virtually impossible to provide appropriate academic instruction, and this level of service precludes meaningful implementation of a student's IEP.

\section{Behaviors of Students With Disabilities}

How often are students with disabilities involved in school violence and disruption? Apart from anecdotal accounts, it is difficult to find authoritative analyses, as data sources are limited. Several sources from recent years, however, present a partial picture and enable us to draw some tentative conclusions. We will examine two reports on implementation of the Gun-Free Schools Act, an analysis of suspensions and expulsions in Kansas, an analysis from Kentucky schools, a look at recent data from Maryland, and data regarding suspensions in Delaware and Minnesota. We also examine a national-level study of suspensions and expulsions by the Research Triangle Institute, a survey of state and local practices from state directors of special education services, and findings in the 21 st Annual Report to Congress on IDEA.

\section{Gun-Free Schools Reports}

Subsequent to passage of the Gun-Free Schools Act of 1994, Congress mandated that annual reports be issued concerning implementation of the Act, including data on involvement of students with disabilities. The Act required each state receiving federal funds under the Elementary and Secondary Education Act (ESEA) to have a state law in effect mandating a minimum 1-year expulsion of students who brought a firearm to school, allowing chief administering officers the right to modify expulsion terms on a case-by-case basis.

During the 1996-97 school year, 6,093 students were expelled from school under the Act. Of the 43 states reporting on shortened expulsions, 39 states reported on the disability status of these students. Of the 699 students reported, $37 \%$ had disabilities under IDEA (U.S. Department of Education, 1998b). During the 1997-98 school year, 3,930 students were expelled from school under the Act. Of the 49 states reporting on shortened expulsions, 48 states reported on the disability status of these students. Of the 1,459 students reported, $38 \%$ had disabilities under IDEA (U.S. Department of Education, 1999c).

\section{Suspensions and Expulsions in Kansas}

Cooley (1995) examined suspension/expulsion data in Kansas, using survey data from 441 secondary school principals. This study found that students with disabilities had more than double the likelihood of suspension/expulsion than students without disabilities. Students with learning disabilities and behavior disorders were disproportionately represented among the students with disabilities who were suspended/expelled, compared to their proportions among students with disabilities in Kansas.

According to the researchers, however, students receiving special education services were no more likely than nondisabled students to engage in injury-causing behaviors. Furthermore, the acts committed by the suspended students with disabilities were found to be no different than those committed by nondisabled students. The report concluded that the students with disabilities were not receiving IEPrelated services appropriate to their needs.

\section{Analysis of Records in Kentucky}

An analysis of records of 465 students in an Eastern Kentucky school district (Fasko, Grubb, and Osborne, 1995) found that about $20 \%$ of the suspended students were disabled, although students with disabilities composed about $14 \%$ of students included in the study. Approximately $83 \%$ of the suspensions were given to male students, and $17 \%$ to females. Males and females made up 53\% and $47 \%$ of the student population, respectively.

\section{Maryland Data}

Data from Maryland (Maryland State Department of Education, 2000) showed that statewide, 64,103 students were suspended during the 1998-99 school year. Of those students, 15,669 (24.4\%) were students with disabilities. Students with disabilities made up $13.1 \%$ of the statewide enrollment that year. Prior Maryland data for the 1997-98 school year (Maryland State Department of Education, 1999) provided an inconclusive picture of suspensions of 
students with disabilities because duplicated and unduplicated counts were mixed, using both incident- and person-specific data. This made comparisons to statewide percent of students with disabilities impossible, because, depending on relative rates of multiple offenses among disabled and nondisabled populations, different conclusions could be drawn.

\section{Suspensions in Delaware}

Along a similar vein, data from a study of suspensions in Delaware (cited in Sinclair and others, 1996) found that $23 \%$ of the incidents resulting in out-of-school suspensions during the 1994-95 school year involved special education students. These data were based on incident counts, not person counts. Therefore, we cannot conclude that $23 \%$ of the suspended students were special education students. Interestingly, the 1997-98 Maryland data (also not conclusive for similar reasons) found that $23.5 \%$ of short-term suspension incidents were associated with students with disabilities.

\section{Suspensions in Minnesota}

A University of Minnesota policy research brief (Sinclair et al., 1996) reported that in Minnesota, the overwhelming percentage of suspensions of students with disabilities involved students with learning disabilities and behavior disorders. The study found that, based on data from several other state studies, about $25 \%$ of suspension incidents were associated with students with disabilities.

\section{Research Triangle Institute Report}

Fiore and Reynolds (1996) conducted an exhaustive study gathering data on discipline issues in special education. The researchers found that for aggregated data from responding states and districts, approximately $20 \%$ of suspended students were students with disabilities, a percentage much larger than their proportion of the student population. Approximately $80 \%$ of the misconduct by students with disabilities was considered less serious, with about $20 \%$ of the misconduct falling into more serious categories. Also, the vast majority of students with disabilities who were suspended were males. Students with emotional disabilities were overrepresented among students with disabilities who were suspended.

The authors noted the paucity of available data on suspension/expulsion of students with disabilities. Only six states and 16 districts provided data on suspensions that included information on students with disabilities. The report demonstrated a tremendous variability among the states with regard to data systems on suspensions and on students with disabilities. The authors urged caution in interpreting the results, as many jurisdictions either had no such datarecording system or failed to provide the requested data. In turn, the available data cannot be construed as a nationally representative sample for students with disabilities.

\section{1st Annual Report to Congress}

The 21st Annual Report to Congress on IDEA (U.S. Department of Education, 2000) addressed school discipline and students with disabilities and reviewed some of the research cited above. Citing a 1994 Office of Civil Rights (OCR) report that found no overrepresentation of students with disabilities among suspended students, the Department of Education report discussed discrepant findings concerning discipline and students with disabilities.

\section{Survey of State Departments of Education}

A survey of state departments of special education (Morgan, Loosli, \& Striefel, 1997) found improvements in maintaining and disseminating behavior standards compared to a similar survey done 5 years earlier. Of the 41 state respondents, 14 states reported that they had no such standards on behavioral procedures. The researchers found considerable variability among the states with regard to maintaining an information dissemination, monitoring, and training system for behavioral procedures for students with disabilities.

\section{Conclusions Drawn from Studies}

Although the data discussed above do not constitute a nationally representative sample of students with disabilities, we can still draw several tentative conclusions from these studies.

1. Mounting evidence suggests that a disproportionately high percentage (possibly close to $20 \%$ ) of suspended students are students with disabilities, compared to a national proportion of about $11 \%$ of students ages 6-21 receiving services under IDEA. One OCR study (cited in the 21st Annual Report to Congress) contradicts this conclusion. Several studies demonstrate that students with learning disabilities and emotional disturbance are overrepresented among suspended students with disabilities.

2. Several studies have found that the majority of suspension-related behaviors seem to be nonviolent and generally do not result in injuries to others.

3. The nature of the suspension-related behaviors of students with disabilities may not be substantively different than the behaviors of the students' nondisabled peers.

4. Some evidence suggests that procedures to guarantee a system of consistent behavioral procedures for students with disabilities vary tremendously among the states and that students in some states may not be receiving appropriate services. Rather, suspension may be the procedure of choice in lieu of more proactive, supportive approaches. 
Research by Mayer and Leone (1999), as well as publications by the Justice Policy Institute and the American Policy Forum (Brooks, Schiraldi, \& Zeidenberg, 2000; Mendel, 2000 ) suggest that punitive, controlling approaches do little to solve continuing problems of school violence and disruption or juvenile crime in the community.

More data regarding specific school experiences with violence, individual school practices, and the role of students with disabilities will be gathered with the new School Survey on Crime and Safety (SSOCS), sponsored by the U.S. Department of Education, National Center for Education Statistics (NCES). NCES plans to conduct the SSOCS every 2 years, and the first SSOCS report is due in December 2000.

Gun-Free Schools Act suspension data revealed 37\%$38 \%$ representation by students with disabilities among cases shortened to less than one year for states reporting disability-related data. While it is logical that a relatively high percentage of cases meriting chief administering officer review would involve examination of disability-related factors, these data raise several concerns. First, the data (U.S. Department of Education, 1998b, 1999c), is a small and possibly unrepresentative subset of the complete dataset, precluding thorough analysis of the situation. The data must be interpreted with caution.

Second, there is reason to believe that often, students with disabilities get caught more often than nondisabled peers, because of problems with social communication, poor judgment, poor planning skills, and attributional biases that can lead to more confrontation with authority figures. These students may be more easily identified by the system for their infractions. That is not to lessen the egregiousness or unacceptability of such behaviors. Rather, it may simply point to a state of affairs in which students with disabilities are represented disproportionately in such cases, in part, because their nondisabled peers are more adept at eluding detection.

Third, the $37 \%-38 \%$ data could be fairly accurate, in which case schools need to develop new understandings and find more effective interventions to reduce weapon-carrying, particularly by students with disabilities. Additional research may shed more light on the exact nature of this phenomenon.

Schools clearly face many challenges in maintaining a safe and orderly environment. The next section presents several approaches to school- and community-based programming.

\section{HOW SCHOOLS HAVE RESPONDED TO PROBLEMS OF SCHOOL VIOLENCE}

\section{Understanding and Shaping School Environments}

School-based violence prevention initiatives are considered a best-practice approach to foster positive youth development
(Dwyer \& Osher, 2000; Mendel, 2000; Walker \& Horner, 1996). Federal and state policy makers increasingly are viewing schools as excellent sites for prevention activities, although federal expenditures for these efforts are relatively modest (Gottfredson, 1997). Schools provide consistent access to youth in the early developmental years, and they employ staff members who are focused on ensuring successful academic and behavioral outcomes for students. Another critical advantage is that many risk factors (see Figure 3) associated with youth violence are school-related and therefore may be modified within school settings.

Schools should consider three fundamental principles when planning violence prevention initiatives. First, evidence strongly supports the effectiveness of school-wide violence prevention initiatives based conceptually on a public health model. This model organizes prevention efforts so that schools can systematically address the needs of all students, including those with severe academic, emotional, or behavioral problems.

Second, approaches that emphasize punishment, control, and containment have been demonstrated to be ineffective in preventing or intervening in disruption and violence; punitive orientations may actually exacerbate school disorder (Mayer \& Leone, 1999).

Third, effective school-wide prevention initiatives are comprehensive, have several components, and involve a broad range of services and supports provided over a sufficient period. Because the antecedents of youth violence are highly correlated (Dryfoos, 1990; Hawkins et al., 2000), prevention programs that address a range of interrelated risk and protective factors have greater potential than singlefocus programs.

The public health approach underlying school-wide violence prevention initiatives was defined by the Institute of Medicine (1994) as a three-tiered ecological perspective incorporating a continuum of strategies at graduated levels of intensity. This model promotes the use of a comprehensive framework of universal, selective, and indicated prevention strategies (Tolan, Guerra, \& Kendall, 1995).

- Universal strategies are the foundation of school-wide prevention efforts because they apply a primary prevention approach to the entire school population. Consistent use of these strategies provides sufficient support for a majority (80\%-90\%) of students in each school, thereby avoiding most instances of new problem behavior. Examples of universal prevention strategies include unambiguous behavioral expectations, proactive classroom management strategies, teacher expectations that support positive student outcomes, opportunities for positive attachment to school, consistent use of incentives and consequences, and school-wide literacy programs. 


\section{FOCUS ON SCHOOLS: CALVERTON MIDDLE SCHOOL}

Calverton Middle School in Baltimore serves nearly 1,200 students in grades 6 through 8 . The school has had a history of low achievement test scores, high rates of student and teacher absenteeism, and discipline problems. Seventy percent of the students at Calverton are eligible for free or reduced-price lunches. During the 1999-2000 school year, 56 of the 85 teachers at the school held provisional or probationary certification. Seven teachers were on long-term leave.

Performance at Calverton was among the lowest for middle schools in the state of Maryland. Daily attendance by students for the 1998-1999 school year averaged 69\%, and during the Fall of 1999, more than 300 students were tardy to school each day. The school was chaotic and experienced frequent interruptions resulting from pulled fire alarms, fights, and classroom disruptions.

Scores on the statewide Maryland School Performance Assessment Program (MSPAP) from 1993-99 indicated that fewer than $6 \%$ of eighth grade students scored excellent or satisfactory in reading and fewer than $5 \%$ of eighth graders scored excellent or satisfactory in mathematics. On the Maryland State Department of Education's Middle School Performance Index (SPI), Calverton scored from 22.57 to 28.24 each year from 1993 to 1999 . The SPI is the weighted average of a school's relative distance from the satisfactory standards, where a score of 100 is considered satisfactory. Several years ago, Calverton was placed on a list of schools eligible for reconstitution or takeover by the Maryland State Department of Education.

In February, 2000, a new principal, Karl Perry, assumed administrative responsibility for Calverton. To begin the process of turning Calverton into an effective and caring school, Perry, with the support of staff, instituted a series of measures designed to refocus the attention of staff and students on academic excellence. Following consultation with other administrative staff, the Five Ps - be Present, Punctual, Prepared, Polite, and Positive-were introduced. Perry's primary objectives in assuming the principalship were to gain control of the school and improve the school climate. Principal Perry also introduced the Drop Everything And Read (DEAR) program, a regular part of the school day at Calverton. He met with parents, local business owners, and members of the community to develop shared strategies to combat truancy and tardiness.

As a result of using an appropriately tailored combination of universal and selective level interventions, Calverton Middle School has showed early signs of improvement. For example, student attendance has risen from about $69 \%$ to over $76 \%$. Tardy arrivals have dropped from about 300 per day during the Fall to about 150 during the Spring semester. Office referrals dropped from more than 2,600 during the Fall semester of 1999 to under 2,200 during the following semester.
- Selective strategies provide increased support for a smaller number of students $(10 \%-15 \%)$ in each school. Secondary prevention strategies such as small-group instruction, social-skills training, behavioral contracting, and mentoring are designed to avoid the escalation of emerging academic and behavioral problems.

- Indicated strategies support a relatively small number of students in each school (1\%-5\%) who demonstrate significant academic or behavioral problems requiring the most intensive level of support. Prevention strategies for these youth are individualized and often involve longterm involvement of education, mental health, social service, and juvenile justice agencies. Wraparound planning (Burns \& Goldman, 1999) and school-based mental health services (Weist \& Warner, 1997; Woodruff et al., 1999) are widely regarded as important advances in violence prevention for high-risk youth.

The variety of strategies incorporated in school-based violence prevention plans can be organized as individual or as environmental approaches. Prevention plans may focus on individual risk factors including alienation from school, truancy, poor academic performance, low levels of social competency, and antisocial behavior in the early grades. More broadly, prevention plans may focus on risk factors in the school and community, such as availability of drugs and weapons, negative peer experiences, and inadequate academic or behavioral support. Although examples of prevention strategies at the individual and environmental level are presented separately below, the interdependence of risk factors calls for integrated approaches that incorporate more than a single type of support.

Strategies frequently included in school-wide prevention plans that target individual risk factors include:

1. Instructional programs (identified as the most common prevention strategy used in schools) (Womer, 1997; Larson, 1994). These curriculum-based approaches focus on a range of social competency and academic skills with the goals of preventing or remediating 


\section{INDIVIDUAL RISK FACTORS}

- Poor academic skills

- Impulsivity

- Substance use

- Poor social problem-solving skills

- Inability to understand the perspective of others

- Poor conflict-resolution skills

- Difficulties in understanding the moral consequences of actions

\section{PEER RISK FACTORS}

- Low social status

- Rejection by peers

- Gang involvement

- Shared deviant peer norms

- Association with delinquent peer groups

\section{FAMILY RISK FACTORS}

- Inconsistent discipline

- Reliance on coercion

- Harsh or abusive discipline

- Poor monitoring of activities

- Insecure attachments

- Defensive communication

- Deviant shared values

- A high percentage of negative interactions

- Low levels of emotional closeness

- Inefficient use of family resources

\section{SCHOOL/COMMUNITY RISK FACTORS}

- Lack of student/parent involvement

- Low academic achievement

- Lack of social organization and social support

- Few opportunities for recreation

- Unemployment and economic disparities

- High levels of community crime

- Availability of firearms

\section{FIGURE 3}

Risk factors for youth violence

Source: A Program Planning Guide for Youth Violence Prevention (1996, p. 15), by N. G. Guerra and K. R. Williams (Boulder, CO: Center for the Study and prevention of Violence). Copyright $(1) 1996$ by the Institute of Behavioral Science, Regents of the University of Colorado. Reprinted by permission.

academic failure, heightening awareness and knowledge of social influences on violent behavior, and teaching appropriate responses to these influences.

2. Behavior-management techniques designed to change antisocial behaviors and promote positive behavioral skills. These strategies will be most effective when based on systematic screening to identify students at risk for antisocial behavior (Sprague \& Walker, 2000).

3. Peer strategies including peer coaching, mediation, and counseling.

4. Counseling and mentoring strategies.

Examples of environmental strategies are a strong academic mission, defining norms for appropriate behavior, promoting student attachment to school, and modifying organizational and structural conditions in the school by decreasing class size and providing a consistent climate of emotional support (Leone, 1997). In this context, prevention strategies should become a normative part of the school routine. For example, programs that teach nonviolent problem-solving strategies have a greater chance for success when the school climate regularly supports and models that approach to conflict (Gottfredson, 1997). School-wide prevention plans should be a high priority for the school and school system, a commitment reflected by strong administrative leadership at the school and district level and the provision of sufficient fiscal resources.

\section{Efficacy of These Approaches}

Although prevention science strongly supports the efficacy of school-wide approaches that incorporate multiple interventions and link schools and their environmental contexts, research on the impacts of these approaches is lacking (University of Vermont, 1999). As a result, numerous prevention initiatives have been implemented but reliable data of their effectiveness are not widely available. Despite the limited availability of rigorous evaluation studies in the 1990s, efforts to document the effectiveness of youth violence prevention programs are increasing. Schools using prevention plans report positive outcomes including improved academic 


\section{FOCUS ON SCHOOLS: RICHARD MONTGOMERY HIGH SCHOOL}

Richard Montgomery High School (RMHS) in Rockville, Maryland, serves approximately 1,650 students in grades 9-12 in a suburban Washington, DC, school district. The school serves a diverse student body that is $12 \%$ African-American, $15 \%$ Asian, $16 \%$ Latino, and $55 \%$ non-Latino Caucasian students. Nearly $9 \%$ of students receive services because of limited English proficiency, $7 \%$ of the students receive special education services, and $10 \%$ of the students receive free and reducedprice meals. The mobility rate at RMHS is $6 \%$. Students at RMHS perform well academically; approximately 500 students in the school are enrolled in the International Baccalaureate program-a rigorous college preparatory program-and $69 \%$ of students attend 2- or 4-year colleges after graduation.

In spite of average daily attendance above $90 \%$ and a strong academic program, the school has had an unacceptably high number of serious disciplinary incidents in recent years. In the 1997-98 school year, there were 35 serious disciplinary incidents at the school, including racial incidents, major vandalism, fights, and drug incidents. Mark Kelsch, a new principal appointed at the beginning of the 1998-99 school year, set out to reduce serious disciplinary incidents and improve academic performance of the school through greater participation and involvement of students and teachers in all aspects of the school. Kelsch's approach-a form of universal or primary prevention-combines a strong emphasis on relationships between adults and students and among students with rules that count and are fairly enforced.

The changes Kelsch has brought to RMHS include a daily 10 -minute televised program produced by students and broadcast throughout the school. The program includes information from the principal, student groups, teaching staff, and others. Other changes include a focus on student achievement and recognition, reorganization of the school schedule so that all teachers in an academic area have common planning time, and consistent enforcement of attendance and tardy policies. These changes appear promising. During the 1999-2000 school year, 12 serious disciplinary incidents occurred-a reduction of nearly two thirds from just 2 years ago. The number of students losing course credit because of unexcused absences and being tardy to class dropped by $50 \%$ from the previous year. This past year Richard Montgomery High School received the Blue Ribbon Award for excellence from the U.S. Department of Education. For more information about the school, visit the web site: http://www.mcps.k12.md.us/schools/rmhs/ performance and staff morale (Dwyer and Osher, 2000), as well as reduced behavior problems, reflected by fewer disciplinary referrals and suspensions (Sugai, Sprague, et al., 2000).

In an exhaustive study of school-based crime prevention efforts, Gottfredson (1997) found positive effects for programs that clarify behavioral norms, offer comprehensive instruction in a range of social-competency skills over a long period, provide behavior modification, and restructure schools to create smaller and more supportive units of instruction. Evidence also points to approaches that are not effective, including insight-oriented individual counseling and peer counseling (Gottfredson, 1997; Tolan \& Guerra, 1998).

Our discussion of the advantages and strategies associated with school-wide prevention approaches is extended in the next section. We also present examples of researchbased, school-wide prevention programs that show promise in reducing school disorder and promoting successful academic and social outcomes.

\section{Promising Approaches}

Numerous programs across the United States have shown positive results. Although it is beyond the scope of this article to review specific programs, we highlight three promising approaches to provide a perspective of the wider prevention and early intervention landscape. The listing of resources and websites (at the end of the article) leads to many other excellent program approaches and models.

\section{Positive Behavioral Interventions and Supports: PBIS}

Positive behavioral interventions and supports (PBIS) is a systems approach to creating and sustaining school environments that foster academic and behavioral competence for all students. As compared with traditional school-based approaches that target problem behavior demonstrated by individual students, PBIS focuses broadly on identifying policies and practices of the school itself that support or impede successful outcomes.

In this approach, classroom management and instructional practices are viewed as parallel processes; effective teaching of both academic and social skills involve strategies such as direct instruction, positive reinforcement, modeling, and precorrection (Sugai, Kameenui, et al., 2000). The PBIS framework emphasizes data-based assessment of the school climate and individual student progress through 
measures such as disciplinary referrals, attendance rates, and suspension rates. Functional behavior assessments are used in response to more intense problem behaviors.

\section{Skill-Building: Violence Prevention Curricula}

Violence prevention curricula based on social learning theory are used widely in school settings to improve students' problem-solving and anger-management skills, and to increase their knowledge of nonviolent responses to interpersonal conflict (Kenney \& Watson, 1999). Conflict resolution and social skills are taught directly as a distinct curriculum or through integration in other coursework.

Numerous models for violence prevention through problem solving are available. For example, an interpersonal cognitive problem-solving approach with demonstrated effectiveness focuses on primary prevention in the elementary grades (Shure, 1999). In this approach, parents and teachers are trained to instruct children directly in using specific thinking and communication skills designed to prevent conflict in school and at home. Second Step is a violence prevention curriculum designed for use in preschool through ninth grade (Frey, et al., 2000). The curriculum emphasizes building protective social and emotional competencies and reducing aggressive and antisocial behaviors.

The Violence Prevention Curriculum for Adolescents (Prothrow-Stith, 1987) is designed to teach alternatives to aggressive behavior and to create supportive classroom environments in urban schools. Evidence suggests that the program is effective in reducing aggressive conflicts among students.

\section{Mental Health and Social Services in Schools:}

\section{Linkages to Learning}

Linkages to Learning is a primary prevention model for the delivery of mental health, health, and social services for at-risk children and their families at 11 elementary and middle schools in Montgomery County, Maryland. The program was established in 1992 as a joint effort among public and private nonprofit agencies to respond to the increased needs of low- income children and their families. Parents are viewed as partners in this effort, taking an active role in developing solutions to individual, family, and community challenges. The overall goal of the program is to address social, emotional, and somatic health problems that undermine children's ability to succeed in school.

Participating children and families receive mental health assessment and counseling; assistance in obtaining shelter, food, housing, and employment; medical/dental care; assistance with immigration, translation, and transportation; and educational support including academic tutoring, mentoring, and adult education classes. Researchers at the University of Maryland completed a comprehensive longitudinal impact evaluation of children in a participating school and a control school (Fox et al., 1999). The evaluation found positive outcomes for children and parents, including improved academic achievement and behavioral functioning at home and school, increased consistency in parenting practices and overall family cohesion.

\section{DEVELOPING A PLAN TO PREVENT SCHOOL VIOLENCE}

In this section we present an overview of the major steps involved in establishing an effective school-wide violence prevention plan.

\section{Assessing school needs.}

Even though fundamental principles for organizing effective prevention plans can be identified and consistently applied, schools cannot follow "one size fits all" formulas or blueprints. The first step in developing a violence prevention plan that incorporates promising practices and responds to the local school context is to conduct a needs assessment.

A systematic needs assessment enables the staff to understand the structural, economic, cultural, linguistic, and developmental variations that influence the functioning of specific schools. The unique features of schools that would be addressed in needs assessment include differences in size and physical structure; personal and cultural attributes of students, staff, and the community; prior experiences with prevention strategies; and current perceptions of the level of order and disorder. Using information gathered in needs assessment helps to shape a school-wide prevention plan that incorporates specific performance goals tailored to the strengths and priorities of each school and community (Walker \& Horner, 1996).

\section{Developing parent and community support.}

Because schools operate within environmental contexts, prevention initiatives that incorporate strong parent and community partnerships can mediate positive outcomes for youth. Kellam (2000) underscores the promise or perils associated with school/community partnerships when he emphasizes that "how prevention program leaders relate to community concerns will dictate the fate of their efforts (p. 2)."

Effective school-wide prevention plans operate best when they involve individual parents and parent organizations in meaningful ways. Parent/school collaboration enhances opportunities for schools to work successfully with troubled youth, extending prevention initiatives beyond schools and into local communities.

Links between the school and the larger community may take many forms, including collaboration among childserving agencies, local business, law enforcement, and advocacy organizations. An important consideration in developing community support is to ensure that violence 
prevention initiatives are culturally competent. This is especially critical given the differential application of school disciplinary practices that result in the disproportionate suspension of African American youth (Townsend, 2000).

\section{Developing a leadership team.}

School-wide prevention plans that are actively supported by school- and district-level personnel, students, and families will likely produce the most effective and durable results. Team-based decision making can enhance ownership and acceptance of school violence prevention plans. Such a leadership team would be composed of staff members representing the various disciplines and roles within the school (e.g., general and special education teachers, counselors and school psychologists, administrators, paraprofessionals), and may include students, parents, and community members. Given the many risk factors associated with youth violence, the leadership team also could function as the organizational mechanism for systematic collaboration with mental health, social service, law enforcement, and other community agencies.

The leadership team conducts and analyzes the needs assessment, formulates short- and longer-term goals, identifies potential prevention strategies, monitors progress, and evaluates results (Dwyer \& Osher, 2000). Teams can be formed specifically to address school-wide prevention efforts, or they can be built from and coordinated with other school-based management teams that exist in many schools.

\section{Providing staff development.}

As is the case in all school reform efforts, staff training is essential to ensure understanding, support, and consistent use of the school-wide violence prevention plan. Carefully designed and implemented training, available for all school staff, operationalizes the concept of a school-wide violence prevention agenda. This training involves teachers, counselors, bus drivers, cafeteria workers, clerical staff, and others working in the school. An important focus of training is skill development that supports achievement of instructional and behavioral competence for all students.

The content of training is also tailored for staff with specialized responsibilities, such as members of the leadership team. Further, given the complex nature of youth violence, staff development should reflect sustained rather than isolated training activities. Inservice training that follows this approach supports the reliable and consistent application of prevention strategies throughout the school.

\section{Evaluating the plan.}

Evaluation is the systematic collection and analysis of relevant data to inform decision making (Muraskin, 1993). Despite growing evidence supporting the use of school-wide violence prevention plans, specific prevention programs and practices have not typically been evaluated through rigorous research. Without benefit of evaluation, school staff and policy makers may respond to troubling behavior based more on political expediency than empirically validated practice.

Evaluation begins with needs assessment and can extend to process, outcome, and cost-benefit research (Flannery, 1998). When examining school-wide prevention programs one or more of the major types of evaluation may be appropriate to use.

- Process evaluations address the qualities that make school-wide prevention programs work or not work.

- Outcome evaluations focus on determining the impact of school-wide prevention programs on the school climate and for individual students.

- Cost-benefit evaluations identify whether specific programs are cost-effective.

Evaluation design has been constrained by difficulties in identifying and measuring outcomes related to prevention of violence in schools (discussed in previous section). Further, the impact of violence prevention programs has not been measured reliably because most evaluations have focused on immediate results in a limited number of sites rather than on longer-term results and replication in different types of schools and communities.

\section{CHALLENGES AHEAD: NEXT STEPS}

Many reports have shown that school and communitybased adolescent violence has been declining in recent years and that schools are considerably safer than surrounding neighborhoods. At the same time, addressing school violence remains an appropriate concern for educators, parents, political leaders, and other members of the community. We've learned from program evaluations, as well as a vast body of research in the fields of education, mental health, social services, and juvenile justice, that school violence must be addressed on the individual, family, school, neighborhood, and larger societal levels. Multifaceted interventions must target specific risk factors, be developmentally appropriate, and be culturally sensitive. In addition, interventions should involve parents and members of the community, promote interagency collaboration, address multiple levels of the child's life (e.g., school, family, neighborhood), and involve an evaluation component.

Schools will continue to face challenges while working with students with disabilities. State and local school systems must develop, disseminate, and monitor the interventions used in addressing behaviors of students with disabilities, using research-based best practices. Schools need to explore alternatives to school suspension, keeping students 
engaged in their school responsibilities and promoting their academic success. Responsive and flexible approaches require, and real progress demands, long-term investment and commitment. There are no quick fixes. Schools should examine their climate and programming to ensure that they are addressing their students' needs. Successful school programs require a buy-in by all school staff-teachers, support staff, and school administration-not just by a particular program's leadership team.

Data collection and analysis of prevention efforts should be ongoing, using rigorous methodology, as exemplified by the PBIS approach (Sugai, Kameenui, et al., 2000). Schooland community-based programs have to maintain ongoing data collection and record keeping and should evaluate student and family needs and progress. At present, the role of students with disabilities in school violence and disruption is not well understood. Meaningful prevention and intervention efforts require thorough understanding of the challenges facing school administrators in serving students with disabilities, particularly those with behavioral problems.

In the face of pressure to offer politically expedient responses to media accounts of school violence and disruption, all members of the community must cultivate a balanced approach to the problem. Parents, educators, administrators, local officials, and other community members should gather accurate information relevant to their community circumstances and needs. A wide range of resources and supports now available from federal agencies, public interest advocacy groups, and private foundations are listed below.

\section{A FINAL NOTE}

Professionals sometimes are affected by the pressures and circumstances of their daily working environment and may react to problems by seeking the most expedient solution. In addressing the complex needs of students with behavioral difficulties, we must force ourselves to take stock of the situation and proceed thoughtfully, in a reasonable and balanced manner. Teamwork and collaboration among all stakeholders, careful study and thorough planning, and a commitment to reflection and self-evaluation all hold the promise of ultimate success.

\section{RESOURCES}

\section{Reports Available On-Line}

Many reports issued under the auspices of the U.S. Department of Education can be obtained (via mail) through the ED Pubs online ordering system at http://www.ed.gov/pubs/edpubs.html
Annual Report on School Safety 1999

available on-line at http://www.ed.gov/PDFDocs/InterimAR.pdf

Early Warning Timely Response available on-line at http://www.ed.gov/offices/OSERS/OSEP/earlywrn.html

Indicators of School Crime and Safety 1999 available on-line at http://nces.ed.gov/pubs99/1999057.pdf

Juvenile Offenders and Victims, 1999 National Report available on-line at http://www.ncjis.org/html/ojidp/nationalreport99/toc.html

Less Hype, More Help (American Youth Policy Forum) available on-line at http://www.aypf.org/whatsnew.htm

Metropolitan Life Survey of the American Teacher, 1999 available on-line at http://www.metlife.com/Companyinfo/Community/ Found/Docs/report9.pdf

Safeguarding Our Children: An Action Guide available on-line at http://www.ed.gov/offices/OSERS/OSEP/ActionGuide/

School House Hype (Justice Policy Institute) available on-line at http://www.cjcj.org/schoolhousehype/ School House Hype II (Justice Policy Institute/ Children's Law Center) available on-line at http://www.cjcj.org/schoolhousehype/

Violence and Youth, Psychology's Response (American Psychological Association, 1993) included free as part of a kit: "Creating Safe Schools: A Resource Collection for Planning and Action [Kit]" Can be obtained (via mail) under "School Safety" category at ED PUBS at http://www.ed.gov/pubs/edpubs.html

\section{Organizations with Websites and On-Line Resources}

Center for Effective Collaboration and Practice (CECP)

Website at http://www.air-dc.org/cecp/

Center on Juvenile and Criminal Justice (CJCJ)

Website at http://www.cjcj.org

Center for the Prevention of School Violence

Website at http://www.ncsu.edu/cpsv/

Center for the Study and Prevention of Violence

Website at http://www.colorado.edu/cspv/

Kentucky Center for School Safety

Website at http://www.kysafeschools.org/

National Center on Education, Disability, and Juvenile Justice (EDJJ)

Website at http://www.edjj.org/

National School Safety Center

Website at http://www.nssc1.org/ 
National Youth Gang Center

Website at http://www.iir.com/nygc/

Office of Juvenile Justice and Delinquency Prevention

(U.S. Dept. of Justice)

Website at http://ojidp.ncjrs.org/

Partnerships Against Violence Network (PAVNET)

Website at http://www.pavnet.org/

Positive Behavioral Interventions and Supports (PBIS)

Website at http://www.pbis.org/english/index.html

Safe and Drug-Free Schools Program

(U.S. Dept. of Education)

Website at http://www.ed.gov/offices/OESE/SDFS/

\section{Books}

Elliott, D., Hamburg, B., \& Williams, K. (Eds.) 1998. Violence in American schools. New York: Cambridge.

Gabarino, J. (1999). Lost boys. New York: Simon and Schuster.

Loeber, R., \& Farrington, D. P. (Eds.) 1998. Serious and violent juvenile offenders. Thousand Oaks, CA: Sage.

Tonry, M., \& Moore, M. H. (Eds.) 1998. Youth violence. Chicago: University of Chicago Press.

\section{REFERENCES}

American Psychological Association. (1993). Violence and youth: Psychology's response. Washington, DC: Author.

Bear, G. G. (1999). Interim alternative educational settings: Related research and program considerations. Alexandria, VA: National Association of State Directors of Special Education, Project Forum.

Biemer, P. P., Groves, R. M., Lyberg, L. E., Mathiowetz, N. A., \& Sudman, S. (1991). Measurement Errors in Surveys. New York: Wiley.

Brener, N. D., Simon, T. R., Krug, E. G., \& Lowry, R. (1999). Recent trends in violence-related behaviors among high school students in the United States. Journal of the American Medical Association, 282(5), $440-446$.

Bronfenbrenner, U. (1979). The ecology of human development: Experiments by nature and design. Cambridge, MA: Harvard University Press.

Brooks, K., Schiraldi, V., \& Ziedenberg, J. (2000). School house hype: Two years later. Washington, DC: Justice Policy Institute.

Burns, B. J., \& Goldman, S. K. (Eds.) (1999). Promising practices in wraparound for children with serious emotional disturbance and their families. Systems of care: Promising practices in children's mental health, 1998 series, Vol. IV. Washington, DC: Center for Effective Collaboration and Practice, American Institutes for Research.

Centers for Disease Control and Prevention. (1997). Recommended framework for presenting injury mortality data. Morbidity \& Mortality Weekly Report, 1997; 46 (No. RR-14): 4-5.

Centers for Disease Control and Prevention. (2000). Fact sheet: Youth risk behavior trends. [online], http://www.cdc.gov/nccdphp/dash/yrbs/ trend.htm

Chandler, K. A., Chapman, C. D., Rand, M. R., \& Taylor, B. M. (1998). Students' reports of school crime: 1989 and 1995. Washington, DC: U.S. Departments of Education and Justice. (NCES 98-241/NCJ169607)

Cook, P. J., \& Laub, J. H. (1998). The epidemic in youth violence. In M. Tonry, \& M. H. Moore (Eds.), Youth Violence (pp. 27-64). Chicago: University of Chicago Press.

Cook, P. J. \& Ludwig, J. (1997, May). Guns in America: National survey on private ownership and use of firearms. Research Brief (NIJ Rep.
No. NCJ-165476). Washington, DC: U.S. Department of Justice, National Institute of Justice.

Cooley, S. (1995). Suspension/expulsion of regular and special education students in Kansas: A report to the Kansas State Board of Education (ERIC Document Reproduction Service No. ED 395 403). Topeka: Kansas State Board of Education.

Dryfoos, J. (1990). Adolescents at risk. New York: Oxford University Press.

Dwyer, K. \& Osher, D. (2000). Safeguarding our children: An action guide Washington, DC: U. S. Departments of Education and Justice, American Institutes for Research.

Elliott, D., Hamburg, B., \& Williams, K. (Eds.). (1998). Violence in American schools. New York: Cambridge.

Farrington, D. P. (1995). The challenge of teenage antisocial behavior. In M. Rutter (Ed.), Psychological disturbances in young people: Challenges for prevention (pp. 83-130). New York: Oxford University Press.

Fasko, D., Grubb, D. J., \& Osborne, J. S. (1995, November). An analysis of disciplinary suspensions. Paper presented at annual meeting of MidSouth Educational Research Association, Biloxi, MS. (ERIC Document Reproduction Service No. ED 393 169)

Felson, R. B. (1996). Mass media effects on violent behavior. Annual Review of Sociology, 22, 103-128.

Fiore, T. A., \& Reynolds, K. S. (1996). Analysis of discipline issues in special education. Research Triangle Park, NC: Research Triangle Institute. (ERIC Document Reproduction Service No. ED 425 607)

Flannery, D. J. (1998). Improving school violence prevention programs through meaningful evaluation. New York: ERIC Clearinghouse on Urban Education. (ERIC Document Reproduction Service No. ED 417 244)

Fox, N., Leone, P., Rubin, K., Oppenheim, J., \& Friedman, K. (1999). Final report on the linkages to learning program and evaluation at broad acres elementary school. Unpublished manuscript, University of Maryland at College Park.

Frey, K. S., Hirschstein, M. K., \& Guzzo, B. A. (2000). Second step: Preventing aggression by promoting social competence. Journal of Emotional \& Behavioral Disorders, 8(2), 102-112.

Furlong, M. \& Morrison, G. (1994). Introduction to miniseries: School violence and safety in perspective. School Psychology Review, 23(2), 139-150.

Furlong, M., \& Morrison, G. (2000). The school in school violence: Definitions and facts. Journal of Emotional \& Behavioral Disorders, 8(2), $71-82$.

Goldstein, S. Z. (1994). Corporate communication: A futurist vision. Communication World, I1(1), 26-28.

Goss v. Lopez, 419 U.S. 565 (1975).

Gottfredson, D. C. (1997). School-based crime prevention. In L. W. Sherman, D. C. Gottfredson, D. L. MacKenzie, J. Eck, P. Reuter, \& S. D. Bushway. Preventing crime: What works, what doesn't, what's promising: A report to the United States Congress. [online] http://www.preventingcrime.com/report/index.htm

Gun-Free Schools Act, 20 U.S.C. § 1415 (e) (3).

Harvard University Civil Rights Project. (2000). Opportunities suspended: The devastating consequences of zero tolerance and school discipline policies. [online] http://www.law.harvard.edu/groups/civilrights/conferences/zero/zt_report2.html

Hawkins, J. D., Herrenkohl, T. I., Farrington, D. P., Brewer, D., Catalano, R. F., Harachi, T. W., \& Cothern, L. (2000, April). Predictors of youth violence. Juvenile Justice Bulletin. Washington, DC: U.S. Department of Justice, Office of Juvenile Justice and Delinquency Prevention.

Hernandez, D. J. (1995). Changing demographics: Past and future demands for early childhood programs. The Future of Children, 5(3), 145-160.

Honig v. Doe, 479 U.S. 1084 (1988).

Howard, H. H. (1995). TV station group and cross-media ownership: A 1995 update. Journalism \& Mass Communication Quarterly, 72(2), 390-401.

Hymowitz, K. S. (2000). Who killed school discipline? City Journal, 10(2), $34-43$.

Ingraham v. Wright, 430 U.S. 651 (1977). 
Institute of Medicine (1994). Reducing risks for mental disorders. Washington, DC: National Academy Press.

Institute for Social Research. (1997). Monitoring the future study. Ann Arbor: University of Michigan.

Kann, L., Kinchen, S. A., Williams, B. I., Ross, J. G., Lowry, R., Grunbaum, J. A., \& Kolbe, L. J. (2000). Youth risk behavior surveillanceUnited States, 1999. Morbidity \& Mortality Weekly Report, 49 (SS-5).

Kaufman, P., Chen, X., Choy, S. P., Chandler, K. A., Chapman, C. D., Rand, M. R., \& Ringel, C. (1998). Indicators of school crime and safety 1998. Washington, DC: U.S. Departments of Education and Justice. (NCES 1998-251/NCJ-172215).

Kaufman, P., Chen, X., Choy, S. P., Ruddy, S. A., Miller, A. K., Chandler, K. A., Chapman, C. D., Rand, M. R., \& Klaus, P. (1999). Indicators of school crime and safety, 1999. Washington, DC: U.S. Departments of Education and Justice. (NCES 1999-057/NCJ-178906)

Kellam, S. G. (2000). Community and institutional partnerships for school violence prevention. In S. G. Kellam, R. Prinz, \& J. F. Sheley, Preventing school violence: Plenary papers of the 1999 Conference on Criminal Justice Research and Evaluation-Enhancing Policy and Practice Through Research (Vol. 2, pp. 1-21). Washington, DC: U.S. Department of Justice, National Institute of Justice.

Kenney, D. J., \& Watson, S. (1999, July). Crime in the schools: Reducing conflict with student problem solving Research brief (NIJ Rep. No. NCJ-177618). Washington, DC: U.S. Department of Justice, National Institute of Justice.

Kerrebrock, N., \& Lewit, E. M. (1999). Children in self-care. The Future of Children, 9(2), 151-160.

Larson, J. (1994). Violence prevention in the schools: A review of selected programs and procedures. School Psychology Review, 23, 151-164.

Leone, P. E. (1997). The school as a caring community: Proactive discipline and exceptional children. In J. Paul, M. Churton, W. Morse, A. Duchnowski, B. Epanchin, P. Osnes, \& L. Smith (Eds.), Special education practice: Applying the knowledge, affirming the values, and creating the future. (pp. 91-103). Pacific Grove, CA: Brooks-Cole.

Lichter, S. R., Lichter, L. S., \& Amundson, D. (1999). Merchandizing mayhem: Violence in popular culture. Washington, DC: Center for Media and Public Affairs.

Loeber, R., Farrington, D. P., \& Waschbusch, D. A. (1998). Serious and violent juvenile offenders. In R. Loeber \& D. P. Farrington (Eds.), Serious and violent juvenile offenders (pp. 13-29). Thousand Oaks, CA: Sage.

Maryland State Department of Education (1999, January). Suspensions from Maryland public schools (1997-98). Baltimore: MSDE Results Branch.

Maryland State Department of Education (2000, January). Suspensions from Maryland public schools (1998-99). Baltimore: MSDE/PRIMInformation Management Branch.

Mayer, M. J., \& Leone, P. E. (1999). A structural analysis of school violence and disruption: Implications for creating safer schools. Education \& Treatment of Children, 22, 333-358.

Mendel, R. (2000). Less hype, more help. Washington, DC: American Youth Policy Forum.

Mercy, J. A., Ikeda, R., \& Powell, K. E. (1998). Firearm-related injury surveillance: An overview of progress and challenges ahead. American Journal of Preventive Medicine, 15(38), 6-16.

Metropolitan Life Insurance Company. (1999). Metropolitan Life survey of the American teacher, 1999: Violence in America's Public Schools. New York: Author.

Morgan, R. L., Loosli, T. S., \& Striefel, S. (1997). Regulating the use of behavioral procedures in schools: A five year follow-up survey of state department standards. Journal of Special Education, 30(4), 456-470.

Muraskin, L. D. (1993). Understanding evaluation: The way to better prevention programs [online], http://ed.gov.offices/OUS/eval/primerl. html

Patterson, G. R. (1982). Coercive family process. Eugene, OR: Castalia.

Prothrow-Stith, D. (1987). Violence prevention curricula for adolescents. Newton, MA: Education Development Center.

Rand, M. (1998). Criminal victimizations 1997: Changes 1996-97 with trends 1993-97._Washington, DC: US Department of Justice, Bureau of Justice Statistics.
Reiss, A. J. \& Roth, J. A. (Eds.). (1993). Understanding and preventing violence. Washington, DC: National Academy Press.

Sheley, J. F. (2000). Controlling violence: What schools are doing. In S. G. Kellam, R. Prinz, \& J. F. Sheley, Preventing school violence: Plenary papers of the 1999 Conference on Criminal Justice Research and Evaluation-Enhancing Policy and Practice Through Research Vol. 2, pp. 37-57). Washington, DC: US Department of Justice, National Institute of Justice.

Shure, M. B. (1999, April). Preventing violence the problem-solving way. Juvenile Justice Bulletin. Washington, DC: U.S. Department of Justice, Office of Juvenile Justice \& Delinquency Prevention.

Sinclair, M. F., et al. (1996, December). On a collision course? Standards, discipline, and students with disabilities, Policy Research Brief, 8(4). Minneapolis: Institute on Community Integration, University of Minnesota. (ERIC Document Reproduction Service No. ED 404 793)

Skiba, R. J., \& Peterson, R. L. (1999). The dark side of zero tolerance: Can punishment lead to safe schools? Phi Delta Kappan, 80(5), 372-378.

Skiba, R. J., \& Peterson, R. L. (2000). School discipline at a crossroads: From zero tolerance to early response. Exceptional Children, 66(3), 335-347.

Snyder, H. N., \& Sickmund, M. (1999). Juvenile offenders and victims: 1999 national report. Washington, DC: Office of Juvenile Justice and Delinquency Prevention.

Sorenson, G. (1993). Update on legal issues in special education discipline. Education Law Reporter, 81, 399-411.

Sprague, J. \& Walker, H. (2000). Early identification and intervention for youth with violent behavior. Exceptional Children, 66(3), 367-379.

Sugai, G. M., Kameenui, E. J., Horner, R. H., \& Simmons, D. C. (2000). Effective instructional and behavioral support systems: A school-wide approach to discipline and early literacy. [online], http://ericec.org/ osep/eff-syst.htm

Sugai, G. M., Sprague, J. R., Horner, R., \& Walker, H. M. (2000). Preventing school violence: The use of office discipline referrals to assess and monitor school-wide discipline interventions. Journal of Emotional \& Behavioral Disorders, 8(2), 94-102.

Taylor-Greene, S., Brown, D., Nelson, L., Longton, J., Gassman, T., Cohen, J., Swartz, J., Horner, R. H., Sugai, G., \& Hall, S. (1997). School-wide behavioral support: Starting the year off right. Journal of Behavioral Education, 7, 99-112.

Tebo, M. G. (2000). Zero tolerance, zero sense. ABA Journal, 86, 40-45.

Tolan, P. H. \& Guerra, N. G. (1994). Prevention of delinquency: Current status and issues. Applied \& Preventive Psychology, 3, 251-273.

Tolan, P. H., \& Guerra, N. G. (1998). What works in reducing adolescent violence: An empirical review of the field. Boulder, $\mathrm{CO}$ : Center for the Study and Prevention of Violence, University of Colorado.

Tolan, P. H., Guerra, N. G, \& Kendall, P. C. (1995). Introduction to special section: Prediction and prevention of antisocial behavior in children and adolescents. Journal of Consulting \& Clinical Psychology, 63(4), $515-517$.

Townsend, B. L. (2000). The disproportionate discipline of African American learners: Reducing school suspensions and expulsions. Exceptional Children, 66(3), 381-391.

Tucker, B. P., Goldstein, B. A., \& Sorenson, G. (1993). The educational rights of children with disabilities: Analysis, decisions and commentary. Horsham, PA: LRP.

U.S. Bureau of the Census, Current Population Reports (1998). Measuring 50 years of economic change using the March current population survey (Rep. No. P60-203). Washington, DC: U.S. Government Printing Office.

U.S. Department of Education, National Center for Education Statistics. Recommendations of the crime, violence, and discipline reporting task force (Rep. No. NCES 97-581). 1996. Washington, DC: National Education Statistics Agenda Committee.

U.S. Department of Education, National Center for Education Statistics (1998a). Violence and discipline problems in U.S. public schools: 1996-1997 (Rep. No. NCES 98-030). Washington, DC: Author, 1998.

U.S. Department of Education, Office of Elementary and Secondary Education and Planning and Evaluation Service. (1998b). Report on state implementation of the gun-free schools act-School Year 1996-97. (Contract N0. EA94052001). Prepared by Westat, Rockville, MD. 
U.S. Department of Education (1999a). Annual report on school safety. Washington, DC: Author.

U.S. Department of Education, (1999b). The Condition of Education 1999. Washington, DC: National Center for Education Statistics. (ERIC Document Reproduction Service No. ED 430 324)

U.S. Department of Education, Office of Elementary and Secondary Education and Planning and Evaluation Service. (1999c). Report on state implementation of the Gun-Free Schools Act-school year 1997-98. (Contract No. EA94052001). Prepared by Westat, Rockville, MD.

U.S. Department of Education (2000). Twenty-first annual report to Congress on the implementation of the Individuals with Disabilities Education Act. Washington, DC: Government Printing Office. Author.

U.S. Library of Congress, Congressional Research Service. Violence in schools: An overview (CRS Report for Congress No. 94-141 EPW). Washington, DC: Author.

University of Vermont. (1999). Prevention strategies that work: What administrators can do to promote positive student behavior. Burlington, VT: Department of Education, School Research Office.

Walker, H. M., \& Horner, R. H. (1996). Integrated approaches to preventing antisocial behavior patterns among school-age children and youth. Journal of Emotional or Behavioral Disorders, 4(4), 194-220.

Walker, H. M. \& Sprague, J. R. (1999). The path to school failure, delinquency, and violence: Causal factors and some potential solutions. Intervention in School and Clinic, 35(2), 67-73.

Ward, J. M. (1999). Children and guns. Washington, DC: Children's Defense Fund.

Weinberg, D. H. (1996). A brief look at postwar U.S. income inequality (Rep. No. P60-191). Washington, DC: U.S. Bureau of the Census.
Weist, M. D., \& Warner, B. S. (1997). Intervening against violence in the schools. Annals of Adolescent Psychiatry, 21, 235-251.

Womer, S. C. (1997). What kinds of school-based prevention programs are publicized? Ellicott City, MD: Gottfredson Associates.

Woodruff, D. W., Osher, D., Hoffman, C. C., Gruner, A., King, M. A., Snow, S. T., \& McIntire, J. C. (1999). The role of education in a system of care: Effectively serving children with emotional or behavioral disorders. Systems of care: Promising practices in children's mental health, 1998 Series (Vol. 3). Washington, DC: Center for Effective Collaboration and Practice, American Institutes for Research.

Yell, M. L. (1990). The use of corporal punishment, suspension, expulsion, and timeout with behaviorally disordered students in public schools: Legal considerations. Behavior Disorders, 15, 100-109.

Yell, M. L., Cline, D., \& Bradley, R. (1995). Disciplining students with emotional and behavioral disorders: A legal update. Education \& Treatment of Children, 18, 299-308.

Yell, M. L. (1998). The law and special education. Upper Saddle River, NJ: Prentice-Hall.

Disclaimer: The opinions stated in this article are those of the authors and do not represent U.S. Department of Education, Office of Special Education Programs or U.S. Department of Justice, Office of Juvenile Justice and Delinquency Prevention (OJJDP) policy. No endorsement of the Office of Special Education Programs, the U.S. Department of Education, or the OJJDP should be inferred.

\section{PERMISSIONS AND COPYRIGHT}

All rights are reserved. No part of this publication may be reproduced, photocopied, faxed, stored in a retrieval system, or transmitted in any form or by any means, electronic, mechanical, recording or otherwise, without the prior written permission of the publisher.
Back issues are available for sale. Reproduction requires permission and payment of fees. It is illegal and a violation of federal copyright law to reproduce this publication without permission. Direct all inquiries to the permissions editor. 